\title{
Photovoltaic Emulator for Grid-connected Quasi-Z-Source Inverter
}

\author{
Zulhani Rasin ${ }^{1}$, Muhammed Fazlur Rahman ${ }^{2}$, Maaspaliza Azri ${ }^{3}$, Md Hairul Nizam Talib ${ }^{4}$, \\ Auzani Jidin ${ }^{5}$ \\ 1,3,4,5 Power Electronics and Drives Research Laboratory, Centre for Robotics and Industrial Automation (CeRIA), \\ Fakulti Kejuruteraan Elektrik, Universiti Teknikal Malaysia Melaka \\ ${ }^{2}$ School of Electrical Engineering and Telecommunications, University of New South Wales, Sydney, Australia
}

\begin{tabular}{l}
\hline \hline Article Info \\
\hline Article history: \\
Received Jun 6, 2018 \\
Revised Jul 5, 2018 \\
Accepted Oct 23, 2018
\end{tabular}

\begin{abstract}
The performance of PV panel is very much dependent on the amount of sun light as well as the temperature of the surrounding environment which normally hard to be predicted. The use of PV emulator in the investigation of solar inverter especially at a lab scale platform helps to mitigate the inconsistency factors due to this uncontrollable variation. This work discussed on the design and development of a PV emulator for the gridconnected quasi-Z-source inverter which has different topology and control method compared to the conventional voltage source inverter. The I-V characteristics of the PV panel is modelled from the commercially available product and through circuit analysis the relation between capacitor voltage control and the PV terminal voltage is established, thus realizing the MPPT operation. Results from both simulation and experimental verification demonstrated that the PV emulator successfully able to produce power for the inverter according to the requirement.
\end{abstract}

Copyright (C) 2018 Institute of Advanced Engineering and Science. All rights reserved.

\section{Corresponding Author:}

Zulhani Rasin,

Power Electronics and Drives Research Laboratory,

Centre for Robotics and Industrial Automation (CeRIA),

Fakulti Kejuruteraan Elektrik, Universiti Teknikal Malaysia Melaka,

Hang Tuah Jaya, 76100 Durian Tunggal, Melaka, Malaysia.

Email: zulhani@utem.edu.my

\section{INTRODUCTION}

Penetration of photovoltaic (PV) based distributed generation system in the energy grid becomes very significant nowdays. Data from the annual report produced by the International Energy Agency as in Figure 1 shows that the PV installation all over the world reaches $98 \mathrm{GW}$ for the year 2017, which is $29 \%$ growth from the previous year with China leading the way by $32 \%$ of the total installed capacity [1].

Along with this rapid development, so as the research activities on the energy conversion aspect of the PV generation system to achieve high efficiency operation. In the design and development of power electronics circuitries for the PV energy conversion, having a stable condition over wide range of input power is important to verify the maximum functionality of the system. Although the sun light during the day is something which is abundantly available, testing a system under certain condition can be very challenging as the wheather and temperature can vary unexpectedly. For that, the use of PV emulator especially for the laboratory scale experimental platform is preferable. Many works have been discussed in the literature among others such as in [2]-[4]. All these works in common, use a lookup data generated from the commercially available PV panel I-V characteristics as a reference. As the PV source can be modelled as a current source input to the system, the PV is then simulated by means of current control using power electronics circuit such as the DC-DC buck converter which is simple and effective. As a result, the power produced by the PV emulator can be specifically controlled to emulate the real environment condition. From the perpective of integration between the PV source and the grid-connected inverter, the DC-DC boost 
converter is preferably used to increase the voltage across the inverter and to implement the the maximum power point tracking (MPPT) to gain maximum power from the PV source [5]-[6].

The Z-source inverter [ZSI] proposed in [7] which then evolves into many other types of impedance source inverters such as the quasi-Z-source inverter (qZSI) [8] which have been proven as an alternative to conventional voltage source inverter (VSI) for the grid-connected PV system with equivalent performance as discussed in the previous works such as in [9]-[12]. Compared to the conventional VSI based PV inverter system, the qZSI eliminates the necessity to have the DC-DC boost converter in between, thus an advantage in term of reducing the number of components as well as on the control complexity. From the point of real PV source implementation however, not very much have been discussed especially on realizing and evaluating the operation and effectiveness of the MPPT, which requires the use of PV emulator as discussed above. For that, this paper is filling the gap by specifically discussing on the implementation of the PV emulator for the case of the qZSI. It is expected that the results from this implementation can be applied to other type of impedance souce as well.

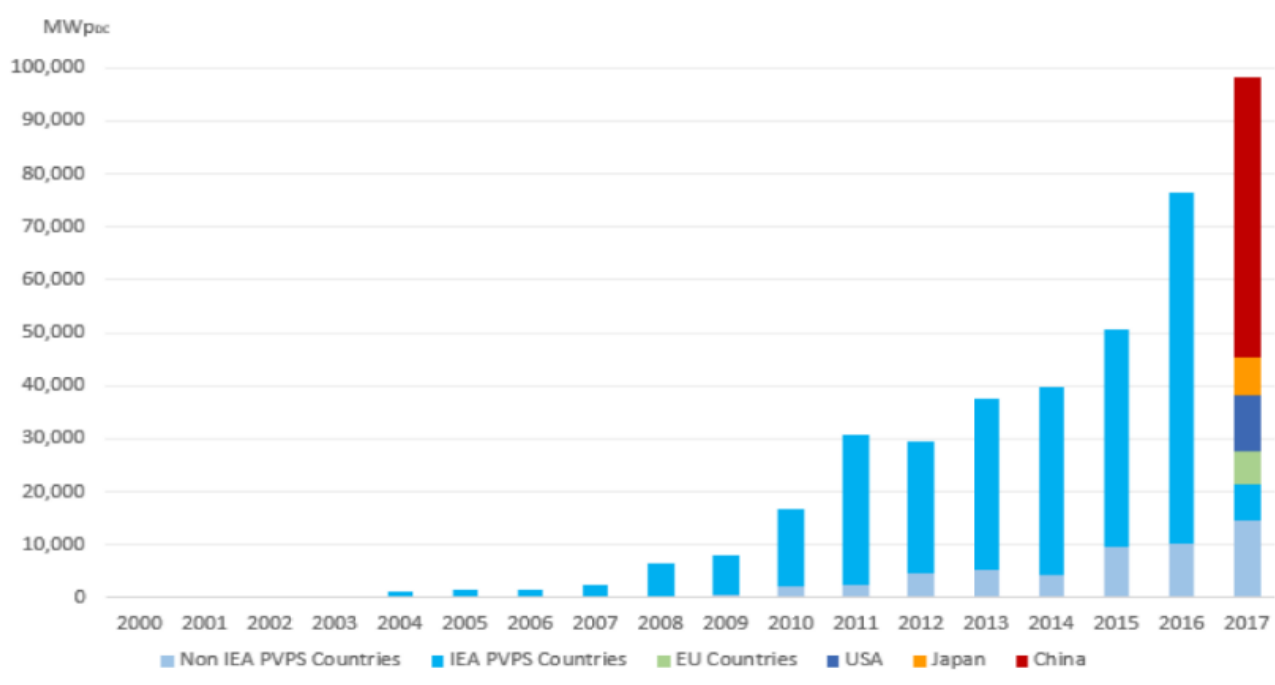

Figure 1. Evolution of annual PV installation (MW-DC) [1]

\section{RESEARCH METHODOLOGY}

\subsection{Modelling of the PV Source Emulator}

Power produced by the solar panel in general varies based on environmental factors such as the amount of sunlight and the temperature. The use of PV source emulator makes it easier to reproduce and maintains the same condition for investigating the performance of the PV inverter system. The PV emulator basically consists of two parts; a lookup table which consists of PV array I-V curve data and the DC-DC buck converter used to generate the current according to the lookup table data provided based on the voltage sensed at its output terminal. Figure 2 shows the structure of the DC-DC buck converter based PV emulator. A general PV array model can be defined from the following Figure 3 which shows the equivalent circuit of the PV cell. The relationship between the output current $I$ and the terminal voltage $V$ is given as [13],

$$
I=I_{s c}-I_{o}\left(\exp \left(\frac{q V_{d}}{A k T}\right)-1\right)-\frac{V_{d}}{R_{p}}
$$

where

$$
\left\{\begin{array}{l}
V_{d}=V+I R_{s} \\
I_{o}=I_{o r}\left[\frac{T}{T_{r}}\right]^{3} \exp \left[\frac{q E_{G O}}{A k}\left(\frac{1}{T_{r}}-\frac{1}{T}\right)\right] \\
I_{s c}=\left[I_{s c r}+K_{I}(T-298)\right] \lambda
\end{array}\right.
$$



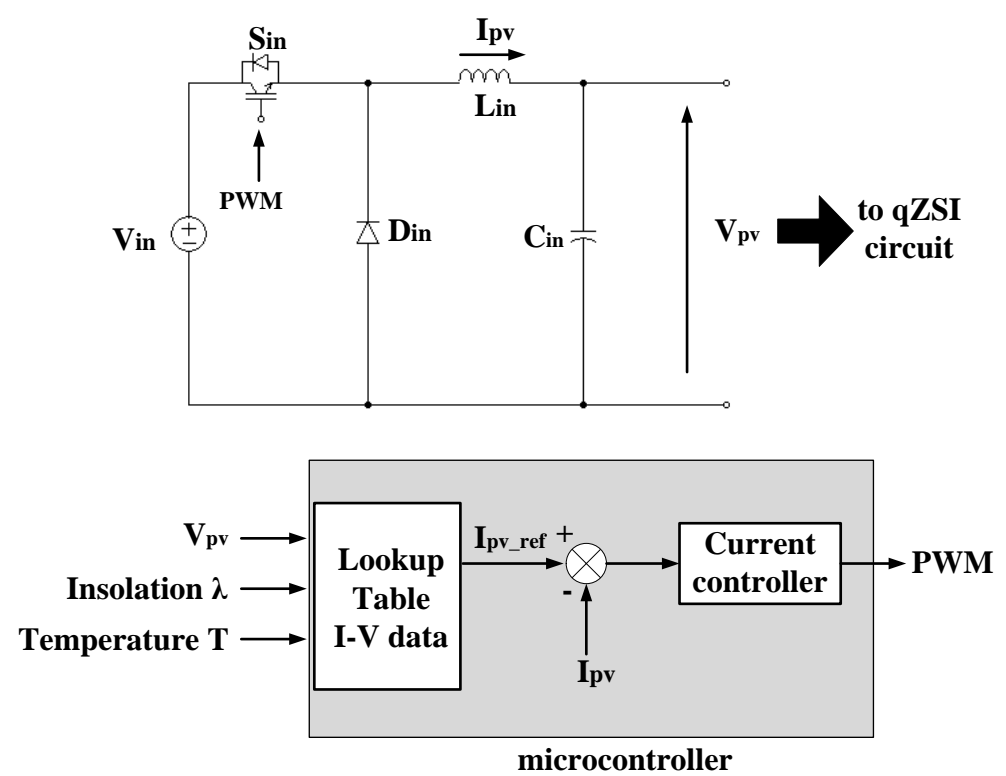

Figure 2. DC-DC buck converter based PV emulator

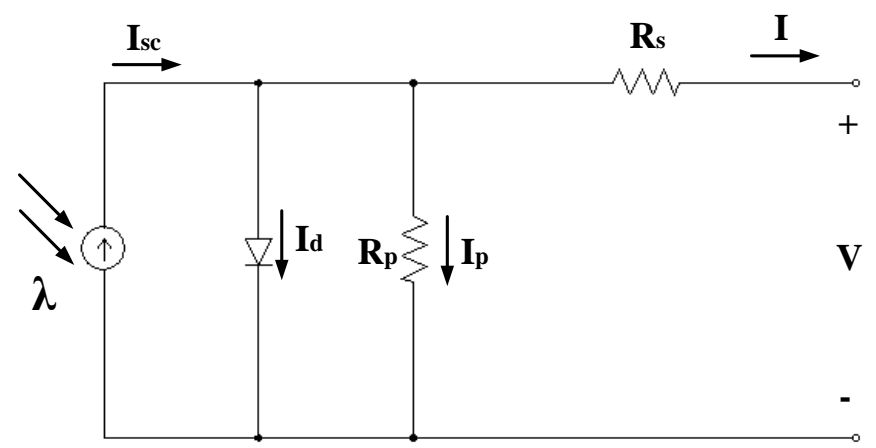

Figure 3. Equivalent circuit for a PV cell

Table 1 shows the definition of parameters involved in the above equations

Table 1. Definition of Parameters for PV Voltage and Current

\begin{tabular}{clcl}
\hline$A$ & Diode ideal dactor & $K$ & Boltzman constant $1.38 \times 10^{-23} \mathrm{~J} / \mathrm{K}$ \\
\hline$T$ & Temperature on absolute scale, $\mathrm{K}$ & $q$ & electron charge $1.6 \times 10^{-19}$ coulombs \\
$\lambda$ & Sunlight insolation $\mathrm{kW} / \mathrm{m}^{2}$ & $I_{o r}$ & Cell saturation current at $T_{r}$ \\
$E_{G O}$ & Band gap for silicon & $T_{r}$ & Reference temperature at $301.18 \mathrm{~K}$ \\
$K_{I}$ & Current temperature coefficient at $I_{s c r} 0.0017 \mathrm{~A} / \mathrm{K}$ & \\
\hline
\end{tabular}

Generally, the PV array consists of $N_{s}$ cell in series to form a panel and $N_{p}$ of panels in parallel according to the rated power required. The output voltage and current are given by the following equations.

$$
\begin{aligned}
& V_{d c}=N_{s}\left(V_{d}-I R_{s}\right) \\
& I_{d c}=N_{p} I
\end{aligned}
$$


Figure 4 shows the graphs voltage-current I-V curve characteristic and the responded power curve calculated based on solar PV panel commercial product BP MSX 120 from BP Solar [14] which is used as the base for the configuration of the PV emulator output voltage, current and power.

\begin{tabular}{|l|c|}
\hline \multicolumn{1}{|c|}{ Electrical Characteristics } & MSX 120 \\
\hline Maximum power $P_{\max }$ & $120 \mathrm{~W}$ \\
\hline Voltage at $P \max \left(\mathrm{V}_{\mathrm{mp}}\right)$ & $33.7 \mathrm{~A}$ \\
\hline Current at $P \max \left(\mathrm{I}_{\mathrm{mp}}\right)$ & $3.56 \mathrm{~A}$ \\
\hline Minimum $\mathrm{P}_{\max }$ & $114 \mathrm{~W}$ \\
\hline Short-circuit current $\left(\mathrm{I}_{\mathrm{sc}}\right)$ & $3.87 \mathrm{~A}$ \\
\hline Open-circuit voltage $\left(\mathrm{V}_{\mathrm{oc}}\right)$ & $42.1 \mathrm{~V}$ \\
\hline Temperature coefficient of $\mathrm{I}_{\mathrm{sc}}$ & $(0.065 \pm 0.015) \% /{ }^{\circ} \mathrm{C}$ \\
\hline Temperature coefficient of $\mathrm{V}_{\mathrm{oc}}$ & $-(80 \pm 10) \mathrm{mV} /{ }^{\circ} \mathrm{C}$ \\
\hline Temperature coefficient of power & $-(0.5 \pm 0.05) \% /{ }^{\circ} \mathrm{C}$ \\
\hline Nominal operating cell temperature & $47 \pm 2{ }^{\circ} \mathrm{C}$ \\
\hline Maximum system voltage & $600 \mathrm{~V}(\mathrm{U} . \mathrm{S} . \mathrm{NEC}$ rating $)$ \\
\hline Maximum series fuse rating & $1000 \mathrm{~V}(\mathrm{TUV}$ Reinland rating $)$ \\
\hline
\end{tabular}

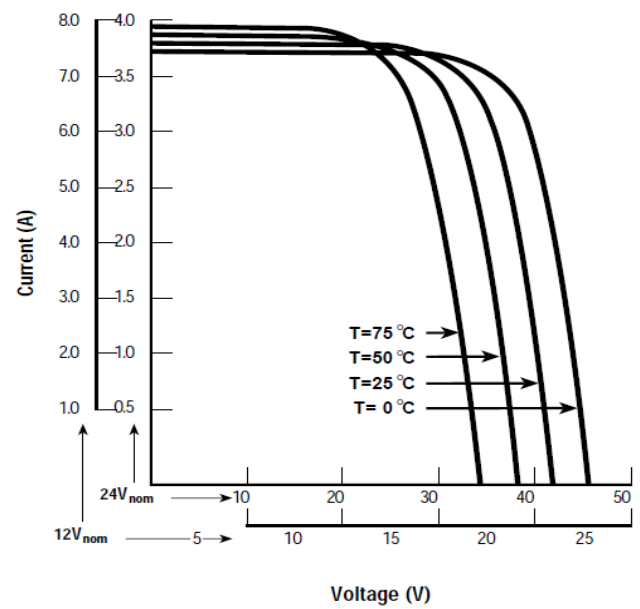

Figure 4. Solar PV panel specification from BP Solar [14] with the electrical characteristics (left) and the I-V curve characteristics (right)

From the circuit and structure of the PV emulator shown in Figure 2, according to the voltage across the output of the DC-DC buck converter, the corresponding reference current is obtained from the lookup table which is produced based from the MSX 120 product in Figure 4. The current controller adjusts the PWM duty ratio so that the average inductor current matches to the reference current. By controlling the average inductor current, the output power of the PV emulator can be controlled to the desired level.

\subsection{Integration of PV Emulator with Grid-connected qZSI}

As shown in Figure 2 the voltage and current output from the PV emulator is connected to the quasiZ-source network which consist of asymmetrical LC network $L_{l}, L_{2}, C_{l}$, and $C_{2}$ plus a diode $D_{l}$. There are two states of operation in the conventional voltage source inverter (VSI); the active states when a non-zero voltage exists across the bridges and the zero states when either all upper and lower transistors are in ON or OFF condition $\left(\mathrm{S}_{1} \mathrm{~S}_{3} \mathrm{~S}_{5} / \mathrm{S}_{4} \mathrm{~S}_{6} \mathrm{~S}_{2} 000\right.$ or 111$)$ to produce a zero voltage condition across the bridges.

In the qZSI, a shoot through condition (short-circuit of inverter switches) is purposely introduced during the zero states. Figure 5 shows the equivalent circuit of qZSI during both shoot-through and nonshoot-through operation.

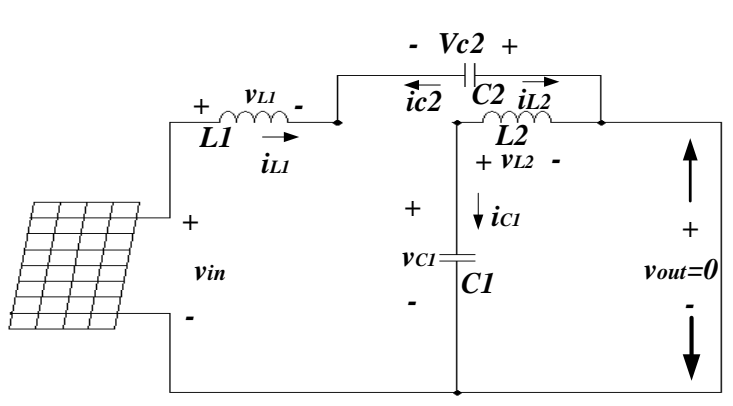

(a)

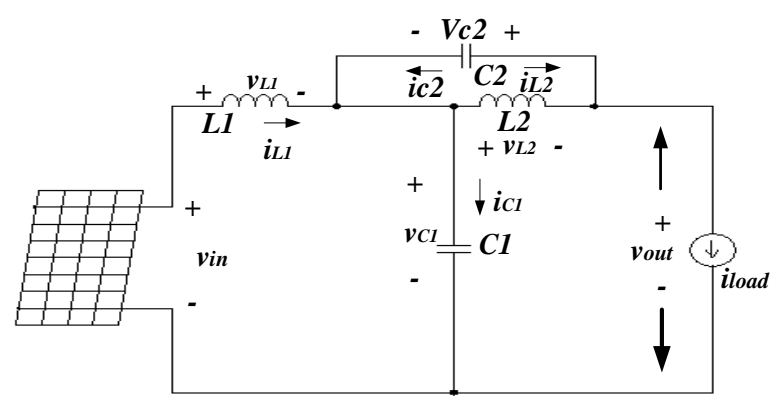

(b)

Figure 5. Equivalent circuit of qZSI during (a) shoot-through and (b) non-shoot-through

The shoot through interval is defined as $T_{0}$, the non-shoot-through interval as $T_{1}$ and the switching period as $T_{s}$ where $T_{s}=T_{0}+T_{1}$. The shoot-through duty ratio $d$ is defined as $d=T_{0} / T_{s}$. When the qZSI is in a 
shoot through condition for a duration of $T_{0}$ from switching cycle of $T_{s}$, using the KCL, KVL, the following equations can be defined.

$$
\begin{array}{ll}
L_{1} \frac{d i_{L 1}}{d t}=v_{i n}+v_{c 2} & L_{2} \frac{d i_{L 2}}{d t}=v_{c 1} \\
C_{1} \frac{d v_{c 1}}{d t}=-i_{L 2} & C_{2} \frac{d v_{c 2}}{d t}=-i_{L 1}
\end{array}
$$

Then when the qZSI is in an active states condition for duration of $T_{1}$ from switching cycle of $T_{s}$, the following equations (5) can be defined.

$$
\begin{aligned}
L_{1} \frac{d i_{L 1}}{d t}=v_{\text {in }}-v_{c 1} & L_{2} \frac{d i_{L 2}}{d t}=-v_{c 2} \\
C_{1} \frac{d v_{c 1}}{d t}=i_{L 1}-i_{\text {load }} & C_{2} \frac{d v_{c 2}}{d t}=i_{L 2}-i_{\text {load }}
\end{aligned}
$$

Considering the average voltage of the inductors and average current of the capacitors are zero over one cycle in steady state, from (4) and (5),

$$
\begin{aligned}
& L_{1} \frac{d i_{L 1}}{d t}=(1-d) \cdot\left(v_{i n}-v_{c 1}\right)+d \cdot\left(v_{i n}+v_{c 1}\right)=0 \\
& L_{2} \frac{d i_{L 2}}{d t}=(1-d) \cdot\left(-v_{c 2}\right)+d \cdot\left(v_{c 2}\right)=0 \\
& C_{1} \frac{d v_{c 1}}{d t}=(1-d) \cdot\left(i_{L 1}+i_{\text {load }}\right)+d \cdot\left(-i_{L 2}\right)=0 \\
& C_{2} \frac{d v_{c 2}}{d t}=(1-d) \cdot\left(i_{L 2}-i_{\text {load }}\right)+d \cdot\left(-i_{L 1}\right)=0
\end{aligned}
$$

From the above equations the capacitor voltage and inductor current can be obtained as,

$$
\begin{aligned}
& v_{c 1}=\frac{1-d}{1-2 d} v_{\text {in }} \\
& v_{c 2}=\frac{d}{1-2 d} v_{\text {in }} \\
& i_{L 1}=i_{L 2}=\frac{(1-d) i_{\text {load }}}{1-2 d}
\end{aligned}
$$

and the DC link peak voltage across the inverter $\hat{v}_{\text {out }}$ can be derived as

$$
\hat{v}_{\text {out }}=v_{C 1}+v_{C 2}
$$

It is shown from (7) and (8) that the capacitor voltage and the DC link peak voltage across inverter can be boosted from $v_{i n}$ by varying the shoot-through duty ratio $d$ accordingly. As for the case the input voltage comes from the output of PV arrays $\left(v_{i n} v_{p v}\right)$, if the capacitor voltage $v_{C l}$ can be controlled to be constant, the input voltage $v_{p v}$ increases when the shoot-through time is decreased, and decreases when the shoot-through time is increased as in equation (9).

$$
v_{p v}=\frac{1-2 d}{1-d} v_{c 1}
$$

Considering this fact for the case of MPPT implementation, the maximum power point voltage $\left(V_{m p p} V_{p v}\right)$ can be tracked by adjusting the shoot-through duty ratio $d$. 
Figure 6 shows the overall configuration of the system with the grid-connected qZSI. It consists of the PV emulator as the main power supply to the inverter system which replicates the behaviour of the actual PV array I-V characteristic, the quasi-Z-source inverter, the local load and the 3-phase $415 \mathrm{~V}$ grid-connection via a transformer.

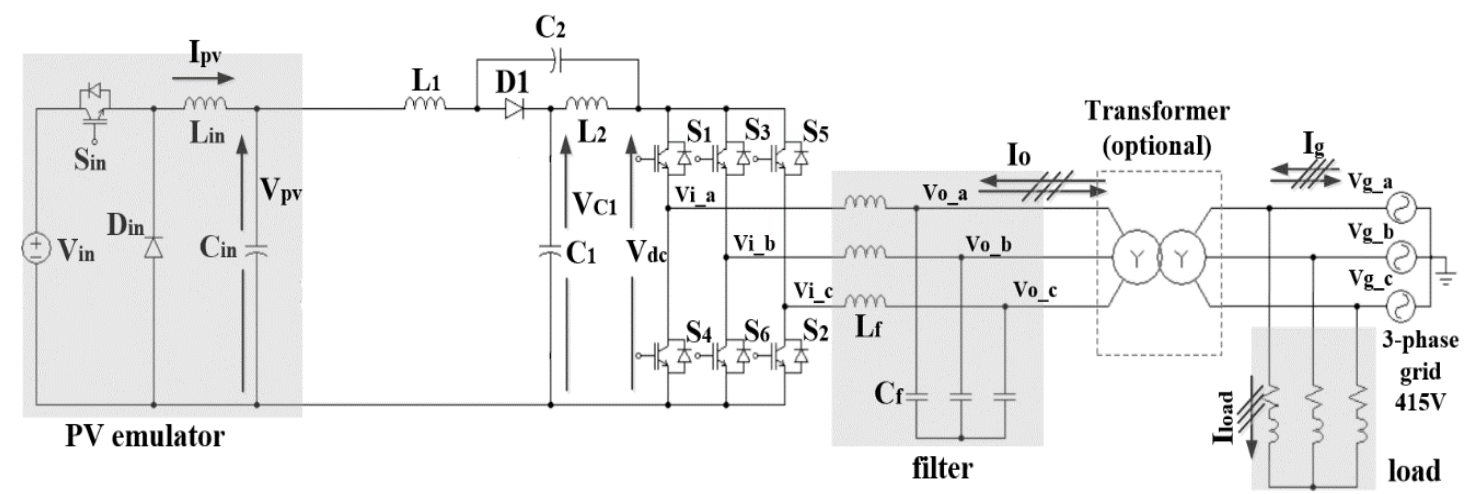

Figure 6. Overall block diagram of the grid-connected qZSI PV inverter system

\subsection{The Maximum Power Point Tracking Alghorithm}

As the capacitor voltage $V_{C l}$ is controlled constantly, the shoot-through duty ratio $d$ is controlled by the MPPT algorithm to regulate the voltage across the PV terminal $V_{p v}$ to achieve the maximum power point according to equation (9). Figure 7 shows the algorithm of the pertube and observe MPPT method (P\&O) [15] used to control the $d$ value. $i$ is the time sequence $V(i)$ and $I(i)$ are the voltage and current at the PV terminal measured by the sensor and the produced power $P(i)$ is computed. Based on the computed $\mathrm{P}(i)$ and the current voltage $V(i)$, decision is made whether to increase or decrease the shoot-through duty ratio $d$.

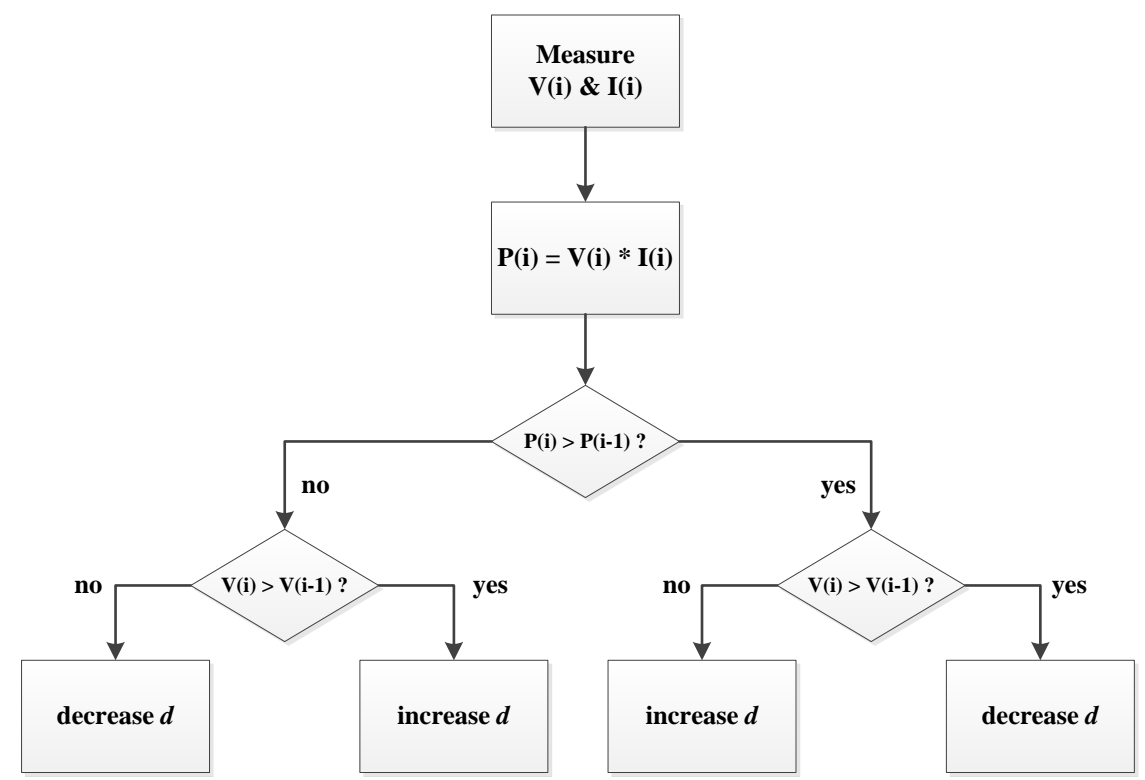

Figure 7. Flowchart of $\mathrm{P} \& \mathrm{O}$ algorithm used to control the shoot-through duty ratio $d$

\section{RESULTS AND ANALYSIS}

Based on the system designed and modelled in the previous sections, simulation using the Matlab® software is carried out with objective of verifying the operability of the designed PV emulator with the gridconnected qZSI PV inverter system. Two platforms of $5 \mathrm{~kW}$ and $0.5 \mathrm{~kW}$ systems are used for the simulation to show the that the proposed method is operable over wide range of power level under residential PV 
installation category. Table 2 shows the parameters and specifications used for both platforms. For the $5 \mathrm{~kW}$ system, the PV source configuration is set at Vmpp $235.9 \mathrm{~V}$ with the capacitor voltage VC1 controlled at 680 $\mathrm{V}$. This makes it possible for direct connection to the 3-phase $415 \mathrm{Vl}-1$ grid. The $0.5 \mathrm{~kW}$ system is the scaled down version of the $5 \mathrm{~kW}$ system, designed with the purpose for comparison with the results from the experiment works presented in the next sub-section. The PV source is configured at Vmpp 141.1 V, with capacitor controlled at $200 \mathrm{~V}$ and connection to the 3-phase $415 \mathrm{Vl}-1$ grid is made through a transformer.

Table 2. Parameters/Specification of Simulation Setup for Grid-connected PV based qZSI

\begin{tabular}{|c|c|c|}
\hline Parameters/Specification & $5 \mathrm{~kW}$ configuration (transformerless) & $0.5 \mathrm{~kW}$ configuration (w/transformer) \\
\hline Max power from $\mathrm{PV}$ & $5 \mathrm{~kW} V_{m p p} 235.9 \mathrm{~V} I_{m p p} 21.36 \mathrm{~A}$ & $0.5 \mathrm{~kW} V_{m p p} 141.1 \mathrm{~V} I_{m p p} 3.6 \mathrm{~A}$ \\
\hline Max power to grid & $5 \mathrm{kVA}$ & $0.5 \mathrm{kVA}$ \\
\hline DC bus voltage & $\begin{array}{l}V_{C l} \text { controlled at } 680 \mathrm{~V}, V_{d c} 1126-1148 \mathrm{~V}_{\mathrm{pk}} \\
\text { shoot-through } d: 0.39-0.41\end{array}$ & $\begin{array}{c}V_{C l} \text { controlled at } 200 \mathrm{~V}, V_{d c} 258-279 \mathrm{~V}_{\mathrm{pk}} \\
\text { shoot-through } d: 0.2-0.3\end{array}$ \\
\hline Switching frequency $\mathrm{f}_{\mathrm{sw}}$ & \multicolumn{2}{|c|}{$10 \mathrm{kHz}$} \\
\hline Grid connection & transformerless 3-phase $415 \mathrm{~V}_{\text {l-1_rms }}$ & $\begin{array}{c}\text { with transformer } \\
\text { 3-phase } 104 \mathrm{~V}_{\text {l-__rms }}: \text { 3-phase } 415 \mathrm{~V}_{\text {l-I rms }}\end{array}$ \\
\hline Grid filter & \multicolumn{2}{|c|}{$L_{f} 10 \mathrm{mH}, C_{f} 8 \mathrm{uF}$ 3-phase $104 \mathrm{~V}_{\text {-1-__rms }}: 3$-phase $415 \mathrm{~V}_{\text {-1-__ms }}$} \\
\hline Standard/reference & \multicolumn{2}{|c|}{$\begin{array}{l}\text { 1. AS } 4447 \text { Grid Connection of Energy Systems via Inverters } \\
\text { 2. IEEE } 1547 \text { Standard on Interconnect Distributed Resources with Elec. Power System }\end{array}$} \\
\hline qZSI network & \multicolumn{2}{|c|}{$L_{l} L_{2} 4.7 \mathrm{mH}, C_{l} C_{2} 1000 \mathrm{uF}$} \\
\hline
\end{tabular}

\subsection{Simulation Results at $5 \mathrm{~kW}$}

Figure 8 shows the I-V curve data used in the simulation for $5 \mathrm{~kW}$ configuration based on the actual PV panel product MSX-120 from BP Solar. From the calculation and the power curve shown below, it is expected the maximum power of approximately $5 \mathrm{~kW}$ can be obtained at approximately $V_{m p p} 235.9 \mathrm{~V}$ and $I_{m p p} 21.36 \mathrm{~A}$ at $25^{\circ} \mathrm{C}$.
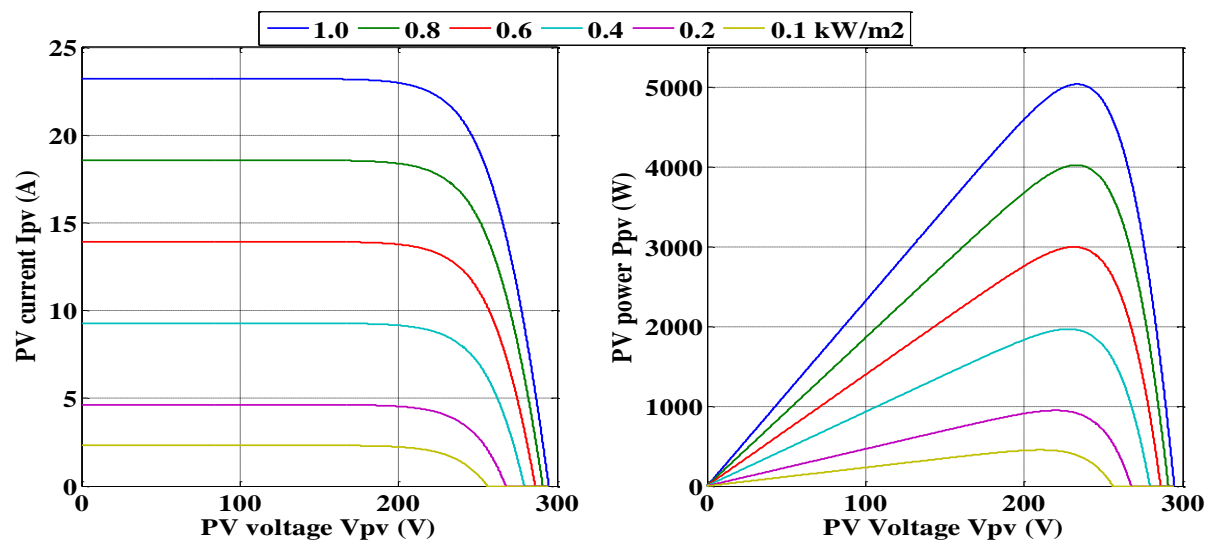

Figure 8. I-V curve data at $5 \mathrm{~kW}$ configuration based on BP Solar MSX-120 PV panel at $25^{\circ} \mathrm{C}$

MPPT operation of the qZSI PV inverter is verified by gradually increasing and decreasing the insolation level between 0.2 to $1.0 \mathrm{~kW} / \mathrm{m}^{2}$ as shown in Figure 9. Variation in insolation value directly affects the power produced by the PV array, and the MPPT operates to find the $V_{p v}$ value that will produce a maximum power. In Figure 9, $V_{p v}$ changes in the range $220 \mathrm{~V}$ to $245 \mathrm{~V}$ through the adjustment in the shootthrough value $d$ between 0.39 to 0.41 . The PV emulator produces the output current $I_{p v}$ based on $I_{p v_{-} r e f}$ in the lookup table which corresponds to the controlled $V_{p v}$ as shown in Figure 10 where the finally produced power $P_{p v}$ is proportional to the given insolation value between $1 \mathrm{~kW}$ to $5 \mathrm{~kW}$. 

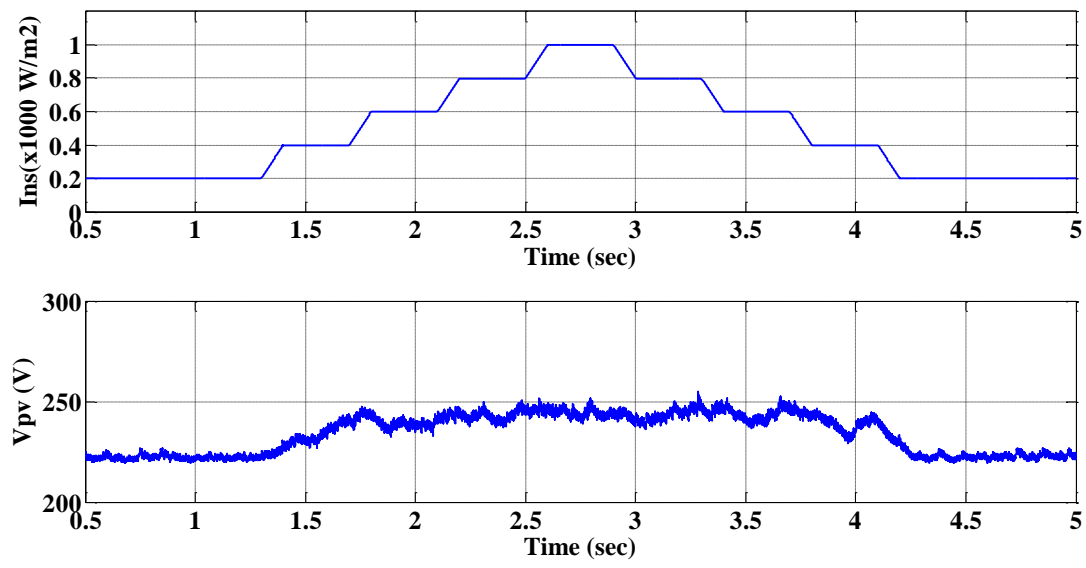

Figure 9. The given insolation level (top) and the changes in the voltage across emulator $V_{p v}$ (bottom)
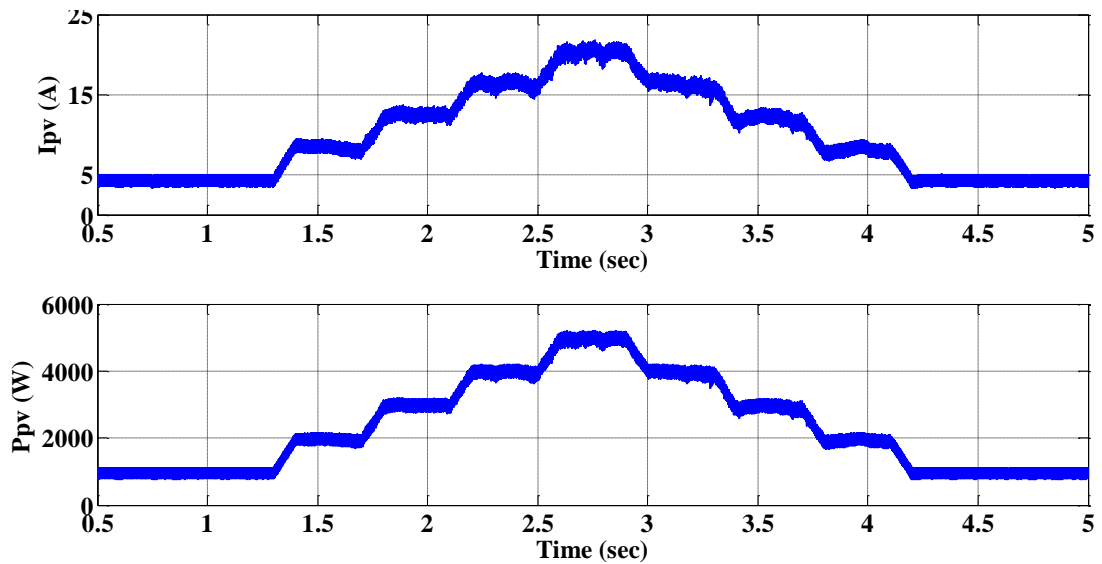

Figure 10. The output current of the emulator $I_{p v}$ and the corresponds output power $P_{p v}$.

The successful operation of the MPPT depends on the ability to control the capacitor voltage $V_{C l}$ which is shown in Figure 11 at around $680 \mathrm{~V}$ with the produced voltage across the inverter switches $V_{d c}$ ranges between $1110 \mathrm{~V}_{\mathrm{pk}}$ to $1140 \mathrm{~V}_{\mathrm{pk}}$. Figure 12 shows the output phase current of the inverter where the value between $2.5 \mathrm{~A}_{\mathrm{pk}-\mathrm{pk}}$ to $9.5 \mathrm{~A}_{\mathrm{pk} \text {-pk }}$ at $339.4 \mathrm{~V}_{\text {phase-pk }}$ is proportional to the power produced by the PV emulator $P_{p v}$.
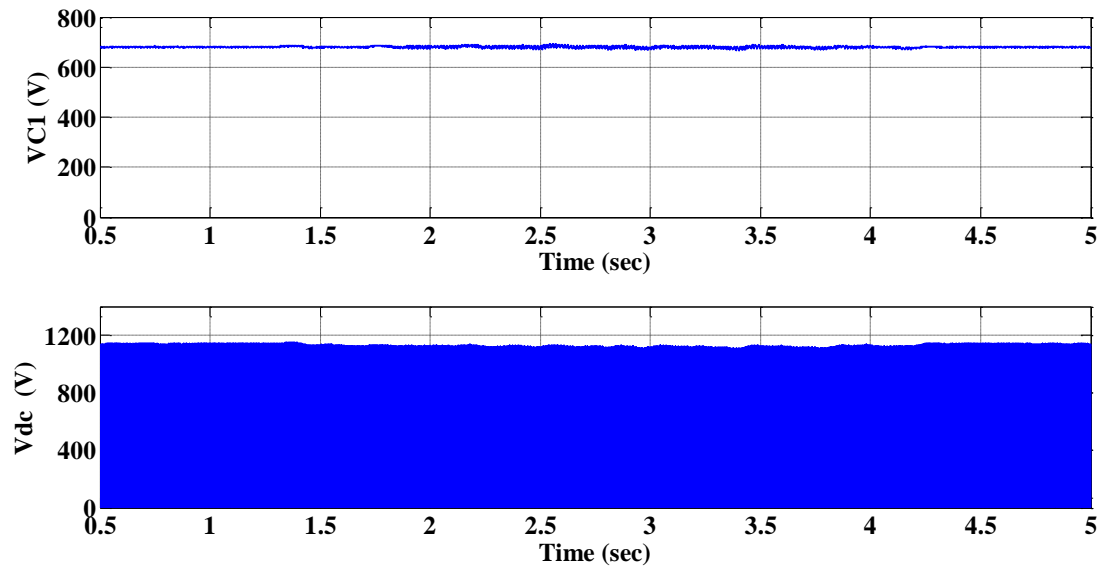

Figure 11. Voltage across $V_{C l}$ (top) and the voltage produced across the inverter switches $V_{d c}$. 


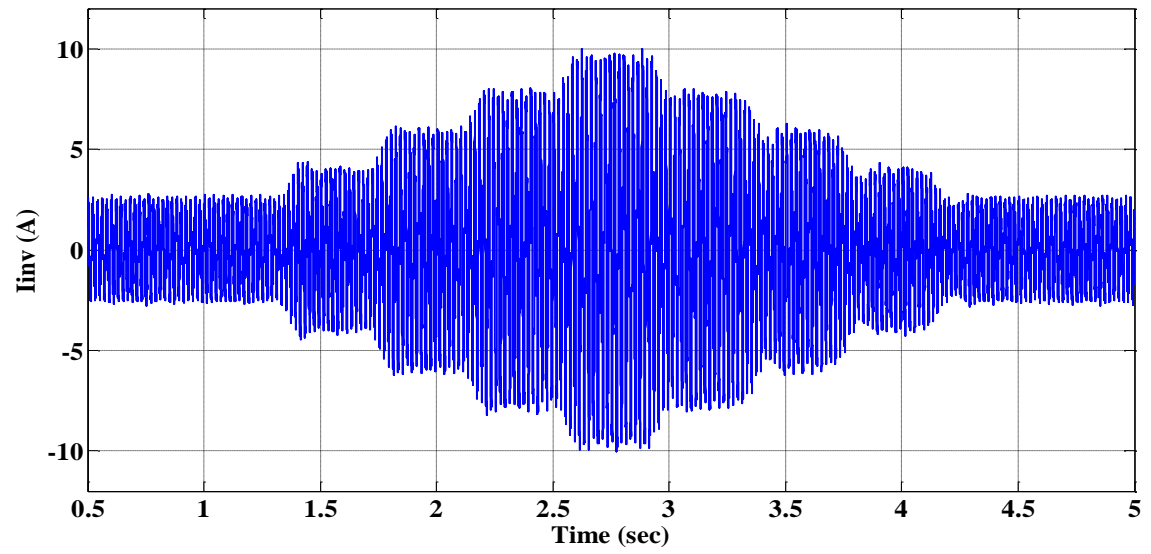

Figure 12. Inverter phase output current

\subsection{Simulation Results at $0.5 \mathrm{~kW}$}

The I-V curve data used in the simulation at $0.5 \mathrm{~kW}$ power level based on commercial product MSX-120 from BP Solar is shown in Figure 13. The maximum power of approximately $0.5 \mathrm{~kW}$ is expected at $\mathrm{V}_{\mathrm{mpp}} 141.1$ and $\mathrm{I}_{\mathrm{mpp}} 3.6 \mathrm{~A}$ at $25^{\circ} \mathrm{C}$. MPPT operation of the qZSI PV inverter is verified through the same manner as for $5 \mathrm{~kW}$ power level and the results are shown in Figure 14. The insolation level is gradually increased and decreased between 0.3 to $1 \mathrm{~kW} / \mathrm{m}^{2}$ at $25^{\circ} \mathrm{C}$. The MPPT algorithm operates to vary the $V_{p v}$ between $120 \mathrm{~V}$ to $145 \mathrm{~V}$ to achieve maximum power $P_{p v}$ at each insolation value ranges between $130 \mathrm{~W}$ to $530 \mathrm{~W}$. The results show a good agreement with the I-V curve characteristic data in Figure 13.

In order to realize the successful operation of the MPPT, the capacitor voltage is controlled at 200 $\mathrm{V}$, shown in Figure 15 (top) and the shoot-through duty ratio $d$ is adjusted between 0.2 to 0.3 . This produces a peak voltage across the inverter $V_{d c}$ ranges between $257 \mathrm{~V}$ to $275 \mathrm{~V}$ in Figure 15 (bottom) which is a good agreement with the theoretical values in Table 2.

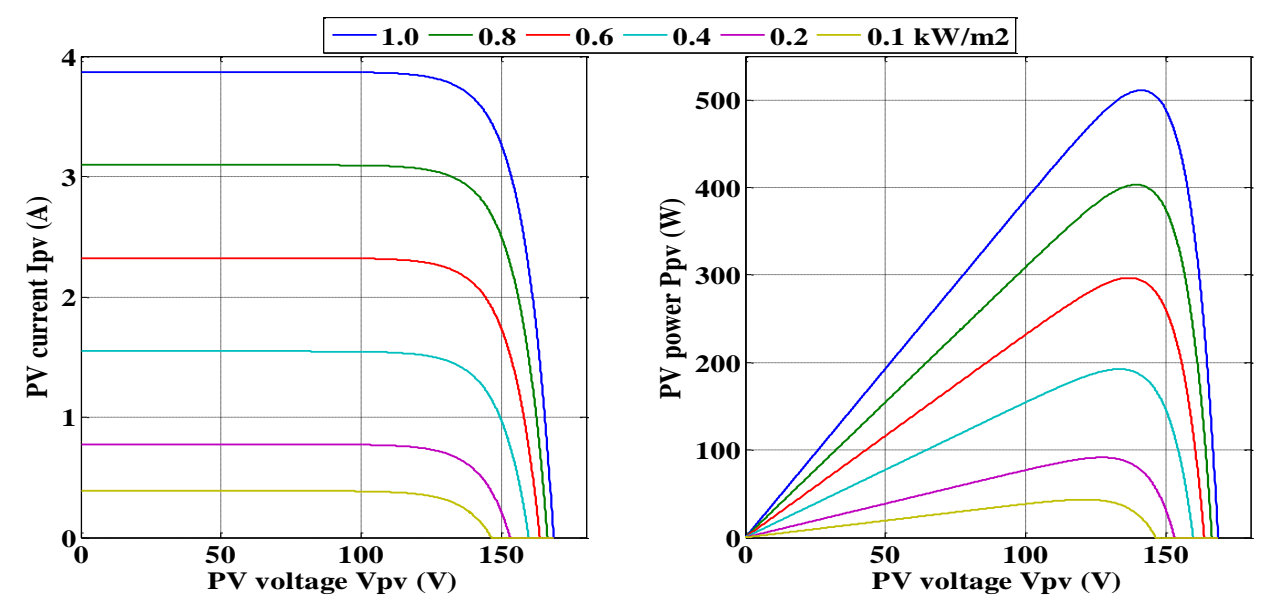

Figure 13. I-V curve data at $0.5 \mathrm{~kW}$ configuration based on BP Solar MSX-120 PV panel at $25^{\circ} \mathrm{C}$ 

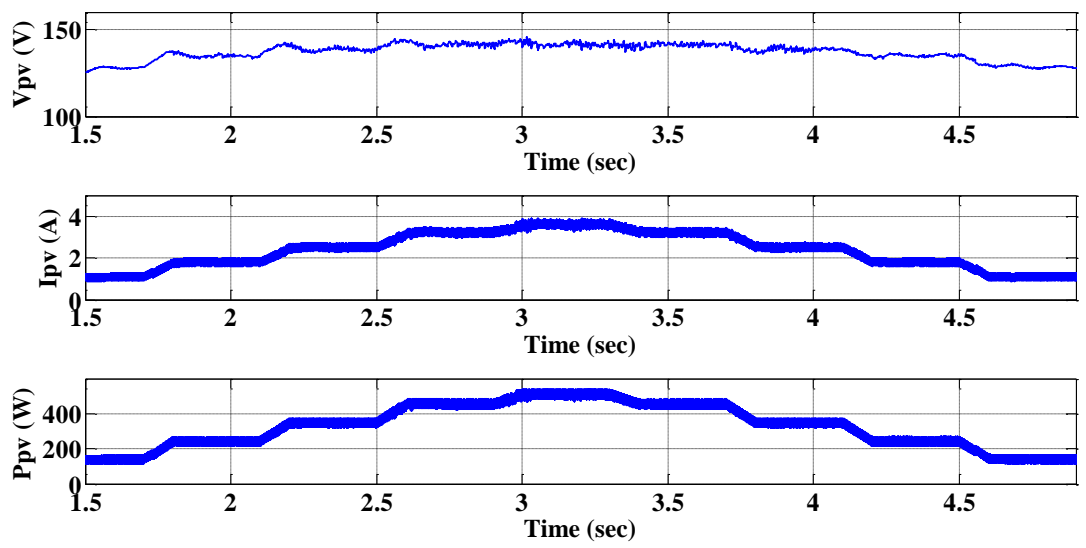

Figure 14. The control of PV source terminal voltage $V_{p v}$ (top) and the corresponds output current $I_{p v}$ (mid) and the produced power $P_{p v}$ (bottom)
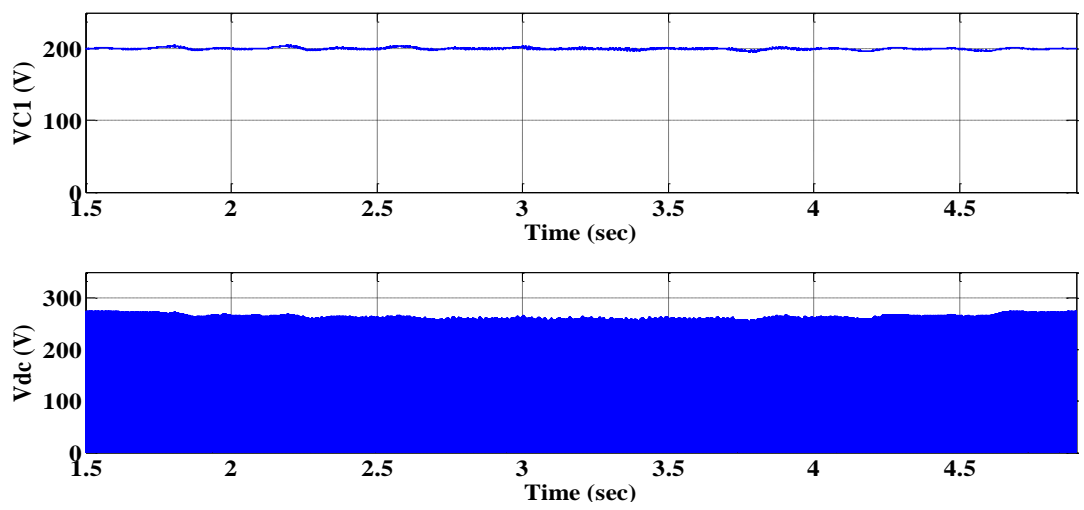

Figure 15. The control of capacitor voltage Vc1 at 200V (top) and the produced peak voltage Vdc across the inverter (bottom)

\subsection{Hardware Experimental Results}

Figure 16 shows the close-up of the PV emulator unit. A digital programmable DC power supply XDC600-10 from Xantrax with maximum voltage of $600 \mathrm{~V}$ and current of $10 \mathrm{~A}$ is used as the power supply. A single IGBT IXEN60N120 from IXYS is used for the switching with breakdown voltage of $1200 \mathrm{~V}$ and current capacity of 100 A. For the gate driver, a gate driver unit based on VLA502-01 from POWEREX is used to drive the IGBT with $5 \mathrm{kHz}$ PWM signal.

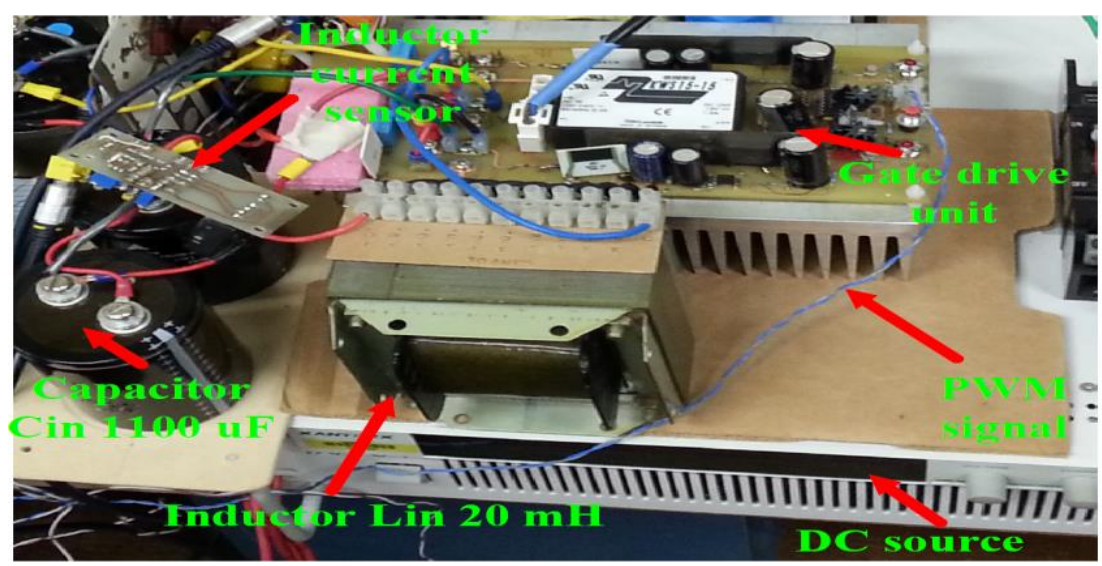

Figure 16. Experiment setup of DC-DC buck based PV emulator 
The DC-DC buck converter is designed to operate at maximum $2 \mathrm{~kW}$ power level, with $V_{\text {in }} 600 \mathrm{~V}$, $V_{\text {out_max }} 200 \mathrm{~V}$ and output current $I_{\text {out_max }} 10 \mathrm{~A}$ with maximum ripple of $20 \%$. Worst case sampling time which is also the switching frequency $f_{s w}$ is made at $5 \mathrm{kHz}$ and duty cycle $D_{\max } 0.35$. In the experimental setup an inductor of $20 \mathrm{mH}$ is used together with two electrolyte capacitor of $2200 \mathrm{uF} / 450 \mathrm{~V}$ connected in series to create a $1100 \mathrm{uF}$ capacitor value.

Figures 17 to Figure 18 shows the results when insolation value is gradually increased and decreased at various level between 0.2 to $1.0 \mathrm{~kW} / \mathrm{m}^{2}$ to produce approximately $100 \mathrm{~W}$ to $500 \mathrm{~W}$ power from the PV emulator. In all cases capacitor $C_{l}$ voltage $V_{C l}$ is well controlled at $200 \mathrm{~V}$ to enable the MPPT operation. The maximum power point is achieved through the increment and decrement of $V_{p v}$ within a range of $120 \mathrm{~V}$ to $145 \mathrm{~V}$ by varying the shoot-through duty ratio $d$ between 0.2 to 0.3 . Inductor current $I_{p v}$ is successfully controlled according to the values $I_{p v \_r e f}$ referred by the I-V lookup table. The power produced by the emulator goes into the inverter and output current of the inverter $I_{i n v}$ is proportional to the input power from the emulator output in Figure 19 (a)-(d). Based on the value of inverter phase output current of 6.43 $\mathrm{A}_{\mathrm{pk}-\mathrm{pk}}$ and $10.25 \mathrm{~A}_{\mathrm{pk}-\mathrm{pk}}$ in Figure 19 (a) and (b), the amount of power produced by the emulator is roughly match the power released by the inverter.
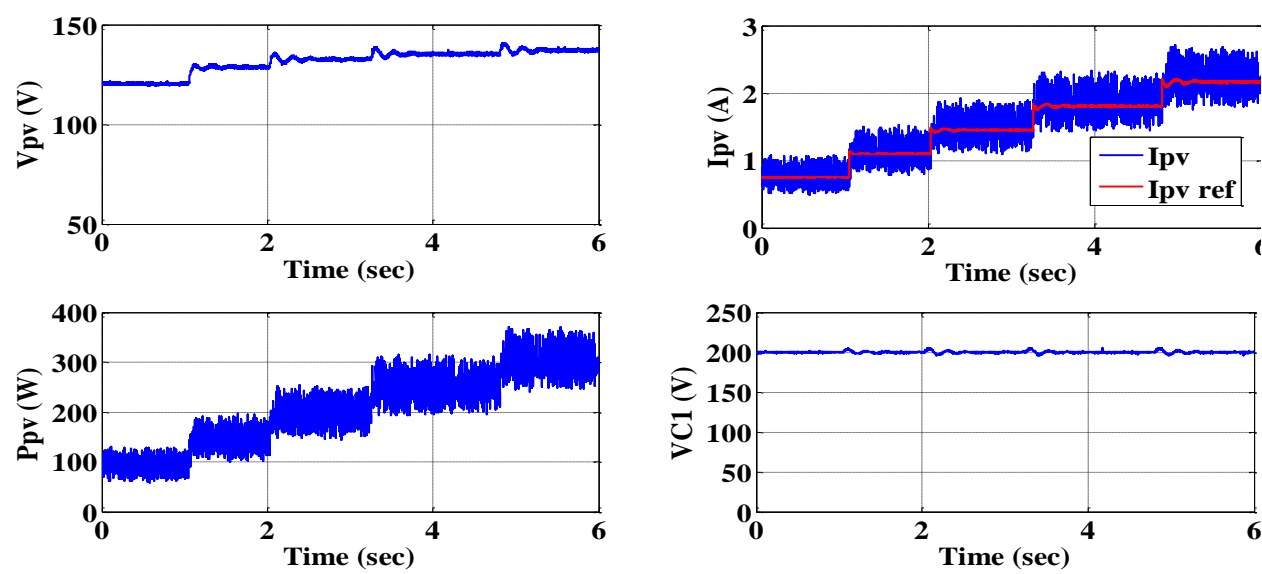

(a)
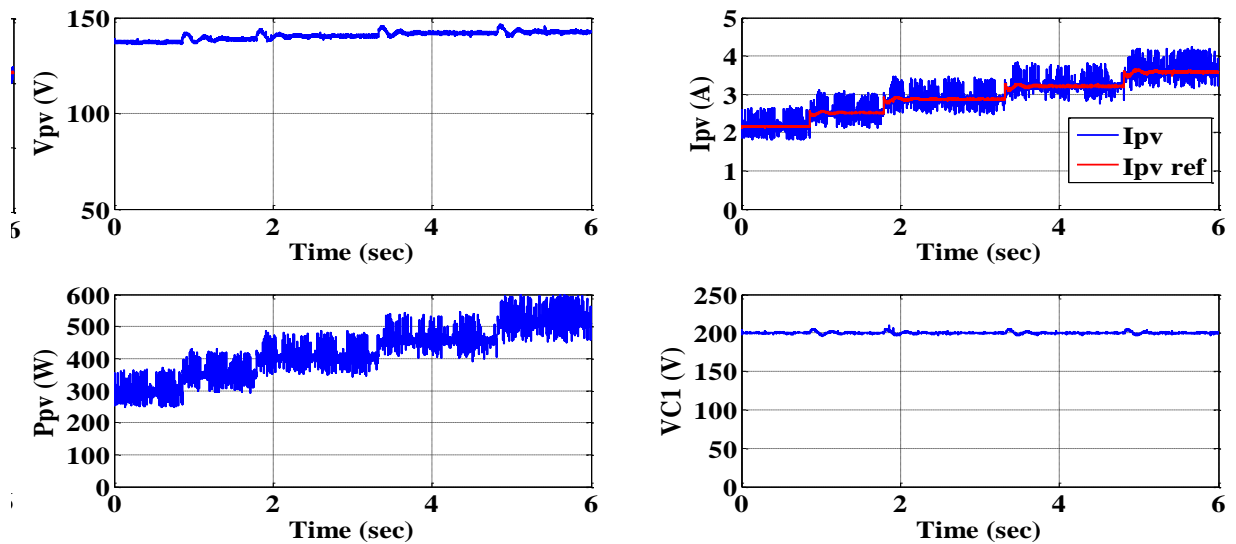

(b)

Figure 17. Variation of emulator output voltage Vpv, current Ipv, power Ppv and control of VC1 for insolation at at (a) 0.2 to $0.6 \mathrm{~kW} / \mathrm{m}^{2}$ and (b) 0.6 to $1.0 \mathrm{~kW} / \mathrm{m}^{2}$

Figure 6-2 Variation of emulator output voltage $V_{p v}$, current $I_{p v}$, power $P_{p v}$ and control of $V_{C l}$ for insolation of 0.6 to $1.0 \mathrm{~kW} / \mathrm{m}^{2}$. 

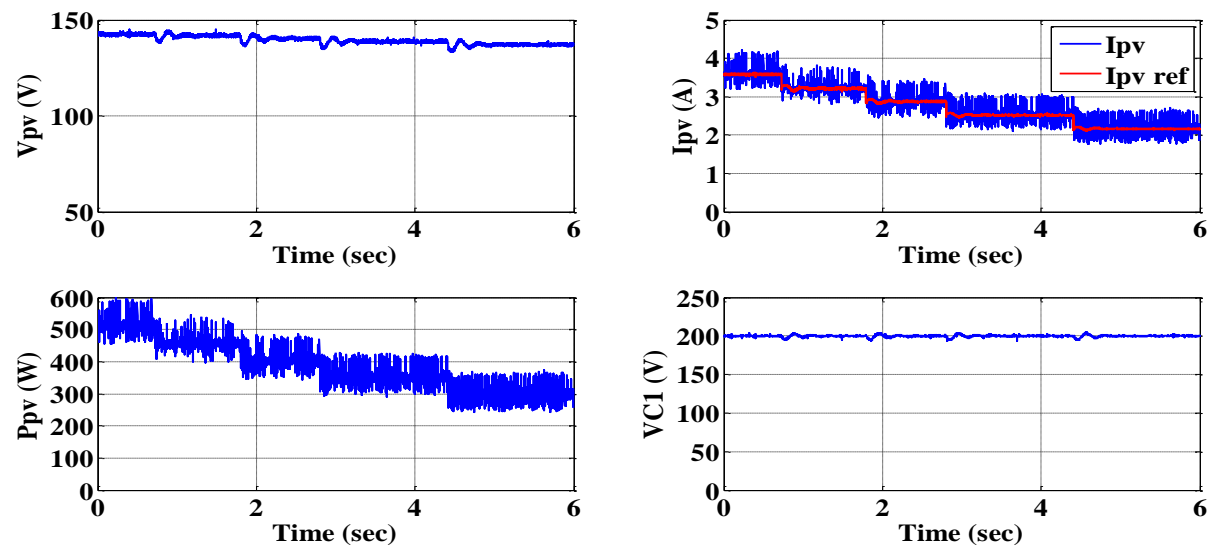

(a)
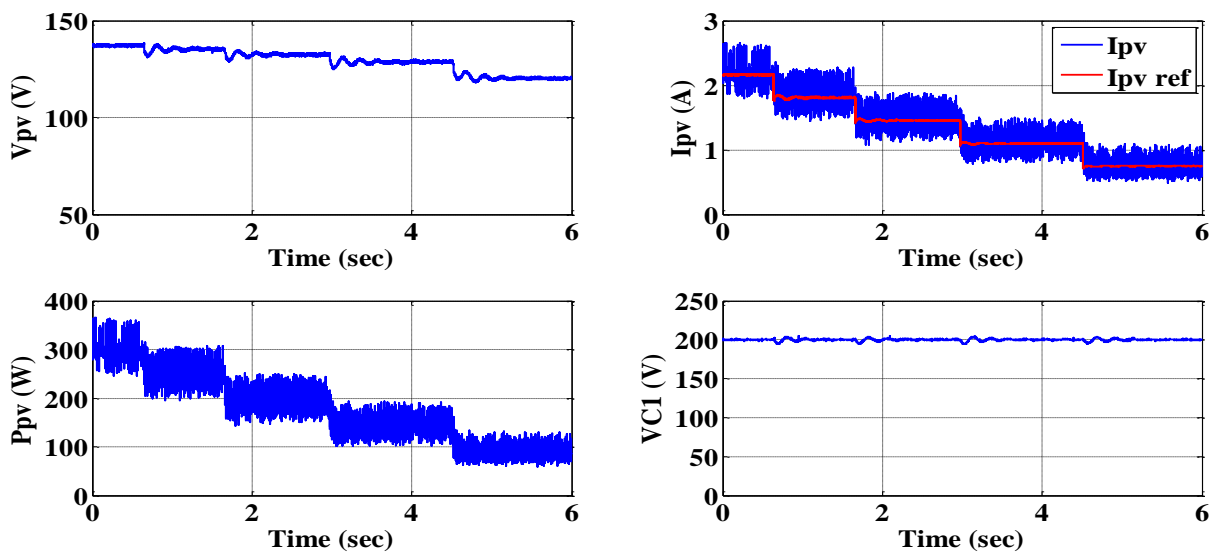

(b)

Figure 18. Variation of emulator output voltage $V_{p v}$, current $I_{p v}$, power $P_{p v}$ and control of $V_{C l}$ for insolation at (a) 1.0 to $0.6 \mathrm{~kW} / \mathrm{m}^{2}$ and (b) 0.6 to $0.2 \mathrm{~kW} / \mathrm{m}^{2}$
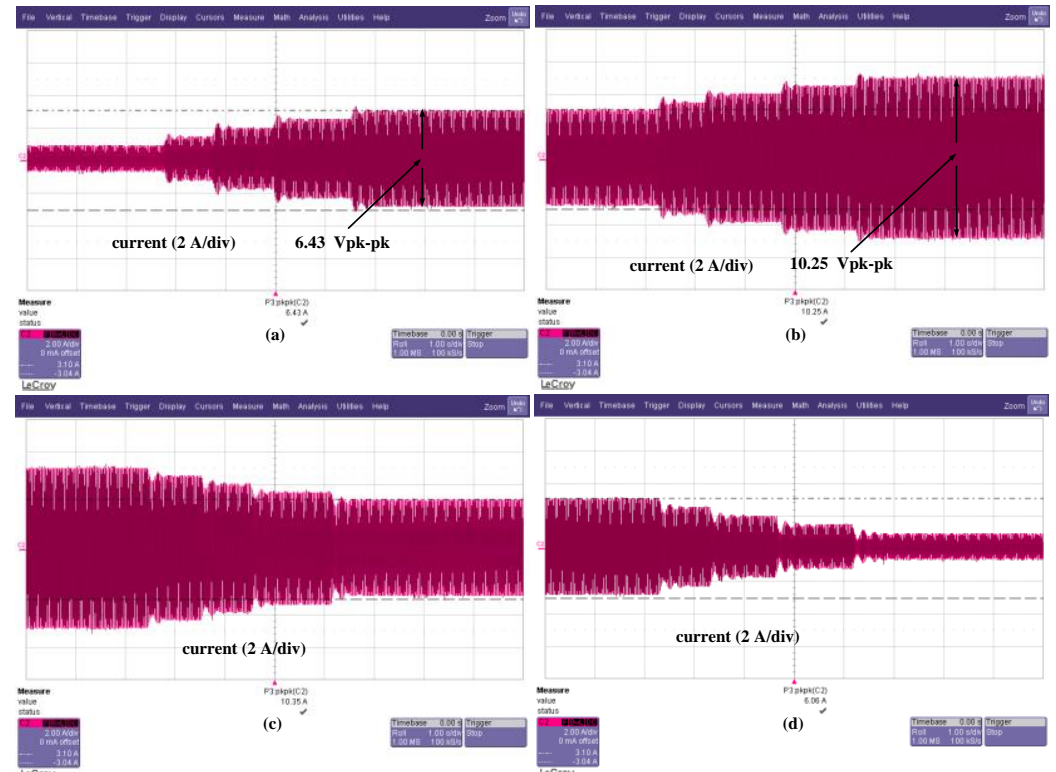

Figure 19. Variation of inverter output phase current $I_{i n v}$ as insolation is increases and decreases (a) 0.2 to 0.6 $\mathrm{kW} / \mathrm{m}^{2}$ (b) 0.6 to $1.0 \mathrm{~kW} / \mathrm{m}^{2}$ (c) 1.0 to $0.6 \mathrm{~kW} / \mathrm{m}^{2}$ and (d) 0.6 to $0.2 \mathrm{~kW} / \mathrm{m}^{2}$ 


\section{CONCLUSION}

The paper presents the design and development of PV emulator for use with the grid-connected quasi-Z-source inverter system. The integration with the qZSI is unique with the elimination of the DC-DC boost converter as normally applied in the conventional VSI topology. The PV emulator is modelled and the I-V characteristics are obtained from the commercially available PV panel product. The overall system of the grid-connected qZSI is configured at two distincts power levels of $5 \mathrm{~kW}$ and $0.5 \mathrm{~kW}$ to show functionality over wide range operation. Based on both simulation and experimental verification results, the PV emulator satisfactorily operates as a current source for the inverter with the MPPT functions well as expected.

\section{ACKNOWLEDGEMENTS}

The author would like to thank the Universiti Teknikal Malaysia Melaka for supporting this work under research grant PJP/2017/FKEHI5/S01470.

\section{REFERENCES}

[1] G. Masson, "2018 Snapshot of Global Photovoltaic Market,” Report IEA-PVPS T1-33:2018.

[2] Azharuddin SM, Vysakh M, Thakur HV, Nishant B, Babu TS, Muralidhar K, Paul D, Jacob B, Balasubramanian K, Rajasekar N. A near accurate solar PV emulator using dSPACE controller for real-time control. Energy Procedia. 2014 Jan 1;61:2640-8.

[3] Balakishan C, Babu S. Development of a Microcontroller Based PV Emulator With Current Controlled DC/DC Buck Converter. International Journal of Renewable Energy Research (IJRER). 2014 Dec 25;4(4):1049-55.

[4] Pelin D, Jukić Antolović J, Rapčan V. PV emulator. International journal of electrical and computer engineering systems. 2014 Jun 11;5(1.):21-6.

[5] Walker, G.R. \& Sernia, P.C. 2004, "Cascaded DC-DC converter connection of photovoltaic modules", IEEE Transactions on Power Electronics, vol. 19, no. 4, pp. 1130-1139.

[6] Walker, G.R. \& Pierce, J.C. 2006, "PhotoVoltaic DC-DC module integrated converter for novel cascaded and bypass grid connection topologies - Design and optimisation", PESC Record - IEEE Annual Power Electronics Specialists Conference.

[7] F. Z. Peng, "Z-source inverter," in Industry Applications Conference, 2002. 37th IAS Annual Meeting. Conference Record of the, 2002, pp. 775-781 vol.2.

[8] Anderson, J. \& Peng, F.Z. 2008, "Four quasi-Z-Source inverters", PESC Record - IEEE Annual Power Electronics Specialists Conference, pp. 2743.

[9] Li, Y., Anderson, J., Peng, F.Z. \& Dichen, L. 2009, "Quasi-z-source inverter for photovoltaic power generation systems", Conference Proceedings - IEEE Applied Power Electronics Conference and Exposition - APEC, pp. 918.

[10] Park, J.-., Kim, H.-., Nho, E.-. \& Chun, T.-. 2010, "Capacitor voltage control for MPPT range expansion and efficiency improvement of grid-connected Quasi Z-Source Inverter", 2010 International Power Electronics Conference - ECCE Asia -, IPEC 2010, pp. 927.

[11] Li, Y., Jiang, S., Cintron-Rivera, J.G. \& Peng, F.Z. 2013, "Modeling and control of quasi-z-source inverter for distributed generation applications", IEEE Transactions on Industrial Electronics, vol. 60, no. 4, pp. 1532-154.

[12] H. Abu-Rub, A. Iqbal, S. Moin Ahmed, F. Z. Peng, Y. Li, and G. Baoming, "Quasi-Z-source inverter-based photovoltaic generation system with maximum power tracking control using ANFIS," IEEE Trans. Sustainable Energy, vol. 4, no. 1, pp. 11-20, Jan. 2013.

[13] Zhang, Hui, Hongwei Zhou, Jing Ren, Weizeng Liu, Shaohua Ruan, and Yongjun Gao. "Three-phase gridconnected photovoltaic system with SVPWM current controller." In Power Electronics and Motion Control Conference, 2009. IPEMC'09. IEEE 6th International, pp. 2161-2164. IEEE, 2009.

[14] BP Solar Global Marketing, "BP MSX-120 Multicrystalline Photovoltaic Module", Spec., 2002.

[15] K. H. Hussein, I. Muta, T. Hoshino, and M. Osakada, "Maximum photovoltaic power tracking: An algorithm for rapidly changing atmospheric conditions", Proc. IEE - Generation, Transmission, Distribution, vol. 142, No. 1, Jan. 1995, pp. 59-64. 